Jurnal Pengajian Melayu - JOMAS, Jilid 32(1), 2021: 156-175

\title{
BIOPOLITIK DAN KRISIS KEDAULATAN \\ DALAM NOVEL LAMPUKI KARYA ARAFAT NUR
}

\author{
(BIOPOLITICS AND THE CRISIS OF SOVEREIGNTY \\ IN ARAFAT NUR'S LAMPUKI)
}

\author{
Cahyaningrum Dewojati \\ cahyaningrum@ugm.ac.id \\ Universitas Gadjah Mada, Yogyakarta \\ Indonesia \\ Moch. Zainul Arifin \\ mochzainul2018@mail.ugm.ac.id \\ Universitas Gadjah Mada, Yogyakarta \\ Indonesia
}

Received: 8 February 2021; Accepted: 12 April 2021

\begin{abstract}
This research aims to analyse the biopolitics and sovereignty crisis in Arafat Nur's novel, Lampuki (2011). The method used in this research was the literary method with data collection, which was by utilising the listening and dialectical methods. This research used Giorgio Agamben's biopolitical theory. The results indicate that the biopolitical transformation of the Achehnese society to the Indonesian state moved into the inclusion process from zoe to bios. However, there are research gaps in the area of inclusion, namely bare life. The Achehnese were not automatically brought into a new political order, but they were circling the area between inclusion and exclusion as well as the politicisation of life. In addition to the past history, the sovereignty crisis occurred and was officially declared by the government. As a consequence from the state of exception, the homo sacers in the novel, Lampuki tend to be civilians. The novel does not merely re-present past conflicts, but also implicitly shows root causes of conflict from biopolitics.
\end{abstract}

Keywords: Biopolitics, State of Exception, Homo Sacer, Novel Lampuki. 


\begin{abstract}
Abstrak
Kajian ini bertujuan menganalisis biopolitik dan krisis kedaulatan dalam novel Lampuki(2011) karya Arafat Nur. Metode yang digunakan dalam kajian ini ialah metode sastera dengan pengumpulan data yang dilakukan dengan metode semak dan dialektik. Kajian ini menggunakan teori biopolitik Giorgio Agamben. Hasil kajian menunjukkan bahawa transformasi biopolitik masyarakat Acheh ke negara Indonesia bergerak dalam proses inklusi dari zoe ke bios. Namun, terdapat ruang yang luput dari perhatian inklusi, iaitu bare life. Masyarakat Acheh tidak serta merta dibawa masuk ke tatanan politik baru, tetapi berputar-putar di wilayah antara inklusi dan eksklusi sekaligus politisasi hidup. Dengan ditambah sejarah masa lalu, krisis kedaulatan terjadi yang dideklarasikan secara rasmi oleh pemerintah. Akibat dari state of exception tersebut figur homo sacer dalam novel Lampuki cenderung masyarakat awam. Di sini novel Lampuki tidak sekadar menampilkan ulang konflik masa lalu, melainkan juga menunjukkan secara implisit akar persoalan konflik dari biopolitik.
\end{abstract}

Kata Kunci: biopolitik, state of exception, homo sacer, novel Lampuki.

\title{
Pendahuluan
}

Pada masa pascareformasi terjadi gerakan separatis di hujung Barat dan di hujung Timur Indonesia, iaitu Acheh dan Papua. Gerakan tersebut, Gerakan Acheh Merdeka (GAM) dan OPM (Organisasi Papua Merdeka), memunculkan tragedi berdarah yang terus dikenang dalam memori bangsa. ${ }^{1}$ Pada masa itu, dalam laporan Amnesty International (2004: 2-6), masalah separatisme Acheh menjadi persoalan yang paling aktual dan dianggap sebagai pelanggaran Hak Asasi Manusia (HAM) serius sebab secara rasmi pemerintah Indonesia mendeklarasikan status darurat militer dan darurat awam di Acheh oleh Presiden Megawati Soekarnoputri pada tahun 2003. ${ }^{2}$ Sejak itu, tercatat begitu banyak yang korban, sekitar 2.879 daripada pihak GAM dan sekitar 662 daripada masyarakat awam di Indonesia. Menurut laporan Amnesty International (1993: 2), deklarasi operasi militer dalam rejim otoriter Orde Baru pernah terjadi pada tahun 1989-1993 yang dianggap sebagai shock therapy terhadap GAM. ${ }^{3}$ Namun, ternyata deklarasi darurat-militer masih dicanangkan pada rejim demokrasi pascareformasi di Indonesia saat itu.

Sebagaimana Giorgio Agamben, ahli falsafah kontemporari Itali, melihat persoalan tersebut dan merumuskan bahawa keadaan-darurat (state of exception) menjadi suatu normaliti dalam negara demokrasi untuk mengekalkan kedaulatannya. Konsekuensi dari keadaan-darurat adalah 1 Majalah.tempo.co - "Hina Jilani: Pelanggaran HAM terbanyak di Acheh dan Papua" edisi wawancara 18 Juni 2007 kepada Hina Jilani yang menyebut pelanggaran HAM terbanyak di Acheh dan Papua.

2 "Kami tidak mentoleransi orang-orang di wilayah ini yang ingin bergabung dalam perayaan separatis. Tidak peduli siapa itu, kami akan menembak mereka di tempat karena mendukung gerakan itu"'. Pernyataan tersebut diucapkan oleh Komandan Korem 011/Lilawangsa yang dicatat dalam buku laporan Amnesty International tahun 2004.

3 Menurut laporan Amnesty Internasional berjudul "Indonesia: 'Shock Therapy' (Restoring Order in Acheh 1989-1993)", operasi militer di Acheh diluncurkan sebagai shock therapy bagi GAM. Namun, dampak dari operasi militer tersebut adalah lebih daripada 300 perempuan dan anak di bawah umur mengalami perkosaan, dan kisaran 9.000-12.000 orang tewas yang sebagian besar warga sipil.

e ISSN 2735 - 1904

https://doi.org/10.22452/JOMAS.vol32no1.10 
terlahirnya kualifikasi hidup-telanjang atau homo sacer (Agamben, 1998, p. 7). Homo Sacer adalah mereka yang terpapar kekerasan secara langsung tanpa ikatan hukum sama sekali sehingga dapat dibunuh tanpa ada konsekuensi apapun terhadap pelaku pembunuhannya. Dari sanalah sebetulnya idea totalitarianisme diam-diam memasuki negara demokratis melalui deklarasi keadaan-darurat. Bertolak daripada hal itu, masyarakat Acheh, baik GAM mahupun awam, adalah homo sacer saat operasi militer berlangsung.

Dalam sejarah kesusasteraan Indonesia, sangat sedikit sekali karya sastera, khususnya novel, yang berbicara tentang konflik Acheh ketika deklarasi status-darurat militer berlangsung pada pascareformasi Indonesia, iaitu Arafat Nur. ${ }^{4}$ Penulis ini banyak menghasilkan novel, cerpen dan puisi yang bertemakan konflik Acheh saat dan pascaoperasi militer di Indonesia $2003^{5}$ silam kerana Arafat Nur tumbuh dan besar dalam gejolak politik dan konflik yang mengancam nyawanya. Pada tahun 1999, Arafat ketika masih remaja diculik oleh suatu kelompok yang mencurigainya sebagai mata-mata kerana menulis puisi dan cerpen. Sekiranya tidak ada pertolongan daripada organisasi kemanusiaan yang mengetahui hal itu, mungkin dia tidak sempat menulis novel dan namanya tidak pernah dikenali. Tidak lama setelah melarikan diri dari penculikan, rumahnya habis dibakar beserta isinya, menyebabkan dia, ayah, ibu, dan empat adiknya tidak mempunyai tempat tinggal lagi. Ayahnya mengasingkan diri ke kampung asalnya di Ulee Gle, Acheh, kerana menderita sakit, sementara ibunya meninggal dunia dalam kondisi sakit dan kelelahan akibat menghindari perang yang tidak ada habisnya. Jadi, sebetulnya Arafat Nur adalah seorang homo sacer pada waktu konflik di Acheh, Indonesia, saat itu.

Seusai perang (konflik) di Acheh, tidak lama setelah pemberontak berjabat tangan dengan pemerintah, dalam kehidupan tidak menentu, miskin, dan kurang makan, tetapi penulis berusaha keras menyelesaikan novel Lampuki (Serambi, 2011) yang selesaikan dalam tempoh tiga tahun kemudian. Pengalaman pahit hidup Arafat Nur ini tampaknya memunculkan ghairah untuk menuliskannya ke dalam karya sastera. Novel Lampuki ini tidak hanya menampilkan tragedi konflik di Acheh melainkan juga secara langsung ditulis oleh sang korban konflik tersebut. Kondisi eksistensial individual ini membezakan seorang pengarang dengan pengarang yang lain (Hassan, 2019 , p. 35-36). Novel ini berjaya menjadi pemenang unggulan pada Sayembara Novel Dewan Kesenian Jakarta, Indonesia, 2010, dan mendapat penghargaan dari Khatulistiwa Literary Award 2011. Terbitnya novel Lampuki menyalakan kemarahan pihak tertentu dengan menghujat dan mencaci maki penulis novel ini, Arafat. Mereka melempari rumahnya dengan batu, dan beberapa kali pengganas menceroboh pintu rumahnya. Namun, Arafat berjaya melarikan diri sampai akhirnya penulis novel ini diceritakan dapat lepas daripada berbagai-bagai ancaman tersebut. Daripada peristiwa tersebut dapat diketahui bahawa beban homo sacer bahkan pascakonflik pun sangat berat untuk menyampaikan pengalaman dirinya terhadap tragedi berdarah tersebut dalam sebuah novel.

4 Helvy Tiana Rossa dalam cerpen 'Jaring-jaring Merah' juga menulis kondisi masyarakat Acheh, khususnya Inong Balee, saat DOM berlangsung di rejim Orde Baru., bukan pada pascareformasi. Sementara, Azhari Ayub, pengarang asal Acheh, juga menulis tentang kondisi Acheh kisaran tahun 2001-2004 dalam cerpen 'Perempuan Pala'.

5 Salah satu novel Arafat Nur yang bercerita tentang pasca konflik 2003 berjudul 'Tanah Surga Merah' (2016). 
Sebelum melangkah lebih jauh, tampaknya kronologis cerita perlu diulas secara singkat supaya mendapatkan inti permasalahan yang tepat. Novel Lampuki ini menceritakan dua tokoh paling menonjol, iaitu Teungku Muhammad, iaitu masyarakat awam dan guru yang mengajar mengaji, dan Ahmadi, iaitu seorang pemberontak atau anggota GAM. Kedua-duanya berasal dari kampung Lampuki, kampung yang menjadi tempat seperti kem penyeksaan penduduk oleh tentera kerana dianggap menyembunyikan pemberontak. Setiap kali Ahmadi dan anak buahnya melakukan penyerangan, maka militer membalas dengan menghajar, memukul, dan memaki-maki setiap penduduk Lampuki baik anak-anak, dewasa mahupun tua. Setiap orang hanya dapat melihat anak mereka, suami atau isteri mereka, datuk nenek mereka dipukul dan dihajar oleh tentera di depan mata mereka. Teungku Muhammad menyalahkan Ahmadi yang bersembunyi di hutan atas perkara yang berulang kali penduduk Lampuki alami. Pada akhir cerita, Ahmadi kembali dengan kondisi yang menyedihkan dan badan kurus kering. Berada sebentar di kampung, Ahmadi dan enam anggotanya langsung meninggalkan kampung. Teungku Muhammad berasa kasihan kepada Ahmadi kerana mereka duhulunya pernah bercengkrama bersama. Teungku Muhammad berasa bahawa kobaran perjuangan Ahmadi sebenarnya telah lenyap, tetapi dirinya harus lari dan terus berlari daripada dikejar oleh tentera yang bersenjata lengkap beserta helikopter. Apabila Ahmadi ditangkap, maka pasti digambarkan akan dibunuh dengan keji.

\section{Permasalahan Kajian}

Berdasarkan hal tersebut, persoalannya berkaitan dengan konsep Hak Asasi Manusia yang sepatutnya melindungi kemanusiaan termasuklah mereka yang berstatus homo sacer. Namun, ternyata terdapat permasalahan dalam konsepsi Deklarasi Universal Hak Asasi Manusia (DUHAM) yang dirumuskan oleh Dewan Majlis Umum PBB tersebut, iaitu konsep HAM hanya dipakai pada konsep nation-state.

Persoalan biopolitik kontemporari inilah yang nampaknya perlu dikaji. Di saat negara membuang warganegaranya sendiri akibat daripada krisis kedaualatan, maka tidak ada undangundang bahkan tanpa hak asasi sama sekali pada tubuh politik mereka. Hal sedemikian kelihatan terjadi pada masyarakat Lampuki, Acheh, Indonesia dalam novel Lampuki. Untuk itu, kajian mendalam terhadap novel Lampuki berkaitan biopolitik dan krisis kedaulatan ini perlu dianalisis.

Dengan demikian, masalah yang diangkat dalam kajian ini: (1) Bagaimana biopolitik dalam novel Lampuki karya Arafat Nur. (2) Bagaimana biopolitik menyebabkan krisis kedaulatan dalam masyarakat dalam novel Lampuki.

\section{Metodologi Kajian}

Berdasarkan pendahuluan di atas, kajian ini menggunakan pendekatan kualitatif yang terdiri daripada objek material dan objek formal. Objek materialnya adalah novel Lampuki karya Arafat Nur yang diterbitkan oleh Penerbit Serambi tahun 2011. Sementara, objek formalnya adalah pemikiran falsafah Giorgio Agamben tentang biopolitik, state of exception, dan homo sacer. 
Metode pengumpulan data dalam kajian ini adalah metode semak dan dialektik. Metode semak dilakukan bermula dari pembacaan novel sampai menemukan data yang sesuai dengan konsep Giorgio Agamben. Sementara itu, metode dialektik dilakukan setelah menemukan data-data yang dikehendaki dan mencari hubungan antara data primer (novel Lampuki) dan data sekunder (surat khabar dan laporan $\mathrm{NGO}$ ).

Teknik analisis data dilakukan dengan cara mencari hubungan antara satuan-satuan teks berdasarkan kerangka berfikir Giorgio Agamben tentang biopolitik, state of exception dan homo sacer. Langkah pertama, peneliti mengklasifikasi data dengan permasalahan kajian. Langkah kedua, peneliti melakukan analisis kandungan dengan cara interpretasi teks. Dalam interpretasi ini, peneliti akan mengintegrasikan teks primer berupa novel Lampuki dan teks sekunder berupa surat khabar, majalah mahupun laporan daripada lembaga swadaya masyarakat berkaitan peristiwa tragedi Acheh. Hal ini dilakukan supaya menemukan pemaknaan yang holistik.

Secara terperincinya, analisis biopolitik masyarakat Acheh dilihat dengan cara meneliti aspek inklusif (diakui) dan eksklusifnya (dibuang) daripada sistem negara-bangsa bernama NKRI (Negara Kesatuan Republik Indonesia). Keadaan terumbang-ambing antara inklusi dan eksklusi masyarakat ini memunculkan krisis kedaulatan, di dalam novel disebut tahun-tahun pembantaian, sementara dalam teks sekunder disebut DOM (Daerah Operasi Militer/Kawasan Operasi Ketenteraan). Selanjutnya, krisis kedaulatan menghasilkan politisasi (pempolitikan) hidup terhadap penduduk Lampuki, yakni sistem undang-undang yang berbeza daripada antropologi masyarakat. Hak hidup dan mati penduduk berada di tangan penguasa yang telah melabel dan menstigmakan mereka. Tokoh-tokoh yang hidup tanpa perisai undang-undang inilah yang disebut homo sacer.

\section{Teori Kajian}

Teori yang digunakan dalam kajian ini adalah Teori Biopolitik Giorgio Agamben dalam bukubukunya yang berjudul state of exception (2005) dan Homo Sacer (1998). Berbeza dengan teori biopolitik para pemikir sebelumnya yang melihat negara sebagai representasi manusia, Agamben melihat biopolitik melalui mekanisme inklusi (diakui) sekaligus eksklusi (dibuang) sebagai warganegara. Biopolitik berasal daripada kata bios (hidup) dan politik. Kehidupan manusia berada di dua wilayah, yakni zoe (hidup-alamiah) dan bios (hidup-politis). Awalnya, manusia seperti binatang yang pada umumnya hidup di alam. Kemudian, dibuatlah tatanan politik supaya hidup menjadi baik (bios). Pada akhirnya, manusia dipaksa terus berada di bios sekaligus ditelantarkan di zoe. Mekanisme dan zon ini disebut sebagai biopolitik.

Setelah manusia dipaksa terus-menerus berada di bios, sementara genus atau hakikatnya manusia tetap sebagai binatang, maka terjadilah keretakan dalam tatanan politik. Keretakan ini dipolitikan oleh penguasa sebagai kedaruratan yang perlu diperbaiki walaupun mengorbankan warganegaranya sendiri. Mekanisme krisis inilah yang disebut state of exception. Dalam momentum itu, muncullah manusia yang hidup telanjang tanpa hukum sehingga boleh dibunuh tanpa ada hukuman bagi si pembunuh. Figur ini disebut homo sacer yang berada di zon antara bios dengan zoe secara berterusan. Biopolitik, state of exception dan homo sacer ini yang dipakai untuk menganalisis novel Lampuki karya Arafat Nur. 


\section{Kajian Lepas}

Beberapa kajian yang memiliki relevansi objek material mahupun objek formal dengan kajian ini adalah seperti yang berikut: Eko Cahyo Prawoto dengan judul "Totalitarianisme dalam Novel Lampuki karya Arafat Nur” dalam jurnal Buana Sastra (2016). Kajian ini membahas totalitarianisme dalam novel Lampuki yang berimplikasi pada fisik, politik, ekonomi dan komunikasi masyarakat. Oleh sebab itu, penerapan hukum justeru melanggar hak asasi manusia.

Arment meneliti novel Lampuki dari segi konflik-konflik yang dinarasikan. Kajian berjudul "Multikonflik dalam Novel Lampuki karya Arafat Nur" ini menemukan bahawa konflik yang terjadi, iaitu konflik interindividu, antarindividu, dan antarkelompok. Konflik-konflik tersebut disebabkan oleh kepentingan antarkelompok, perbezaan kebudayaan dan perbezaan status sosial.

Muhammad Alfian pernah menggunakan objek formal falsafah Giorgio Agamben dalam tesisnya yang berjudul "Novel Maryam sebagai Kritik terhadap Politik Kedaulatan dan Politik Kewarganegaraan di Indonesia" di UGM pada tahun (2019). Kajian ini menemukan bahawa jemaat Ahmadiyah di Lombok menjadi homo sacer dalam novel Maryam. Oleh sebab itu, novel Maryam diajukan sebagai kritik terhadap politisasi hidup warganegara ahamdiyah di Lombok.

\section{Dapatan Kajian dan Perbincangan}

\section{A. Biopolitik}

Transformasi biopolitik masyarakat Acheh ke Republik Indonesia hampir mirip dengan yang dituliskan oleh Arafat Nur dalam novel Lampuki. Pada bahagian awal novel ini menceritakan asalusul daripada nenek moyang bangsa Acheh hingga menjadi bahagian dari NKRI (Negara Kesatuan Republik Indonesia). Hal tersebut terdapat pada Bahagian 1 novel Lampuki yang diberi subjudul 'Khotbah Berapi-api pada Larut Malam'. Khotbah yang berisi sejarah politik suatu bangsa tentu menjadi persoalan apabila disampaikan pada masa autoritarian Orde Baru di Indonesia. Namun, sebelum bahagian satu novel ini terdapat sebuah prolog yang menggambarkan latar waktu, tempat dan kondisi suatu kampung yang bernama Lampuki. Daripada prolog inilah difahami bahawa latar waktu pada novel ini sekitar akhir tahun 1998, akhir pemerintahan Orde Baru Soeharto. Dengan demikian, saat itu ditandaikan kondisi Indonesia telah bertransisi daripada otoritarianisme ke negara demokrasi. Dengan kata lain, dalam negara demokrasi seharusnya hak masyarakat awam untuk berpendapat secara bebas di ruang awam terjamin.

Kebebasan berpendapat itu dimanfaatkan tokoh Ahmadi untuk menceritakan sejarah kejayaan bangsa Acheh pada Bahagian 1 novel ini. Khutbah sejarah yang berapi-api Ahmadi ini menjadi pijakan biopolitik bekerja pada masyarakat Acheh. Diksi 'khotbah berapi-api' itu cenderung mengarah kepada orasi politik Ahmadi. Daripada orasi politik inilah digambarkan masyarakat Acheh bergabung dengan Negara Kesatuan Republik Indonesia.

Biopolitik yang diperkenalkan oleh Agamben mempersoalkan cara warga negara di negara demokrasi moden dikonstruksikan (Sudibyo, 2019, p. 56). Dikotomi antara zoe (hidup-alamiah) dan bios (hidup-politik) diletakkan dalam demarkasi hierarki bahawa hidup-politik adalah hidup 
yang baik, sedangkan hidup-alamiah yang tanpa hukum negara adalah hidup yang rendah. Oleh sebab itu, manusia yang baik adalah yang masuk ke dalam aturan politik negara dengan tujuan kebaikan bersama, dan dalam istilah Aristoteles disebut polis. Hal ini tampak dari orasi politik Ahmadi tentang bujuk rayu tokoh Karno (yang dimaksud kemungkinan besar ialah Presiden Soekarno) agar Acheh bergabung bersama-sama membentuk Negara Kesatuan Republik Indonesia. Perhatikan petikan berikut.

\begin{abstract}
Waktu itulah Karno menyingkir kemari, menyelamatkan diri dari kejaran penjajah kolonial sebab Belanda tidak pernah mampu menguasai tanah ini. Selagi di sini, dia menjumpai Teungku Daud yang lagi gigih-gigihnya memimpin perjuangan rakyat dalam upaya mengusir penjajah Belanda yang hendak meluaskan wilayah jajahan, setelah berkali-kali mereka gagal menaklukkan sedepa tanah ini, dan mereka masih bersikeras, bertekad bulat menaklukkan Acheh atas dasar gengsi semata. Karno tahu betapa besarnya maruah dan pengaruh lelaki bersongkok hitam yang amat dipuji dan dipatuhi rakyat di sini; yang orang-orangnya terkenal paling pemberani, beringas, nekat, dan agak pesong. Lelaki itu memanfaatkan peluang kebaikan Teungku Daud dengan siasat yang mengelabui benak dan hati ulama itu.
\end{abstract}

(Lampuki, 2011, p. 26)

Hal ini menunjukkan adanya sejarah penuh gejolak peperangan untuk mempertahankan tanah air baik Acheh mahupun Indonesia. Oleh sebab ada musuh bersama iaitu Belanda, Karno digambarkan dalam novel ini pergi ke Acheh untuk mencari perlindungan kerana Acheh pada saat itu merupakan tanah yang mampu bertahan daripada gempuran Belanda. Dalam catatan sejarah Indonesia, Soekarno memang pernah datang ke tanah Acheh pada bulan Jun 1948, yang bermaksud tiga tahun setelah proklamasi kemerdekaan Indonesia pada 17 Agustus $1945 .{ }^{6}$ Ketika itulah dalam novel ini digambarkan tokoh Karno memujuk untuk mempersatukan bangsa Acheh yang ditokohi Teungku Daud dengan bangsa Indonesia yang saat itu dipimpin Karno supaya Indonesia mampu mengusir Belanda. Perhatikan petikan berikut.

Semua penduduk negeri ini adalah keturunan bangsa agung dan mulia. Kaum malang ini berasal dari para petualang hebat dan tangguh, datang kemari dengan mengarungi laut raya dari negeri-negeri yang jauh di seberang laut sana. Indatu kami adalah orang-orang terpelajar dari Peringgi, China, India, Arab, dan Parsi. Pandai dalam ragam pengetahuan dan cakap melakukan segala pekerjaan; dari beternak, cocok tanam, seni, pertukangan, agama, berdagang, pertabiban, firasat, pemerintahan, nujum, siasat, sampai urusan perang.

6 Laporan khusus Tempo edisi 17 Ogos 2003 berjudul "Beureueh, Pemberontakan dengan Sebab Klasik”. Terdapat keterangan yang menunjukkan bahawa pada masa perjuangan Daud Beureueh membantu Sukarno dalam mengusir penjajah. Namun, setelah itu Daud Beureueh merasa dikhianati oleh Sukarno. 
"Sejak zaman kejayaan hingga sebelum keruntuhannya, tiada satu pun bangsa di dunia ini yang mampu menaklukkan kita. Jangankan mengotori perempuan, menyentuh pun mereka tidak kuasa. Namun, kaum seberang yang kita hormati, yang kita berikan emas dan pesawat terbang, malah menyerang kita. Mereka menjarah kekayaan, membunuh orang-orang, lalu mengangkangi perempuan!" entaknya dengan kumis bergetar

(Lampuki, 2011, p. 24)

Petikan ini memperlihatkan asal-usul bangsa Acheh yang sebenarnya daripada ragam etnis dan suku yang berbeza-beza mampu hidup jaya bernuansa kebanggaan. Indatu (atau founding fathers) bangsa Acheh ialah orang-orang yang kuat dan berwawasan luas. Ahmadi menceritakan romansa sejarah ini kepada pemuda desa Lampuki untuk memberikan kontras antara keadaan dahulu dengan keadaan sekarang. Dahulu bangsa Acheh jaya, tetapi sekarang sengsara. Hal ini dapat dilihat di bahagian '...namun, kaum seberang yang kita hormati, yang kita berikan emas. . . malah menyerang kita'. Yang dimaksud kaum 'seberang' dalam novel ini adalah pemerintah pusat di Jawa. Menurut tokoh Ahmadi, bangsa Jawa berhutang kepada bangsa Acheh, tetapi malah dibalas dengan serangan ke bangsa Acheh. Hal yang menyakitkan ini disampaikan oleh Ahmadi. Lebih jauhnya dapat dilihat pada petikan berikut:

Ahmadi mengatakan bahawa sesungguhnya pendahulu-pendahulu kami yang perkasa tidak pernah tunduk dan takluk kepada bangsa mana pun di dunia. Mereka amat lihai dan mawas terhadap siasat serta gelagat musuh yang hendak menipu dan menghancurkan kerajaan. Namun sesudahnya, malah mereka sendiri yang saling menghancurkan bangsa megah ini. Keadaan itu semakin diperparah oleh seseorang yang bebal dan pongah, yang menyerahkan bangsa besar ini ke selangkang seorang lelaki seberang yang melagakkan dirinya sebagai pemimpin besar Nusantara pada masa depan.

$$
\text { (Lampuki, 2011, p. 24-25) }
$$

Lantaran yakin betul akan linangan air matanya, lanjut Ahmadi, hati lelaki tua itu luruh tersentuh, dan menyerukan kepada sekalian rakyat agar mengumpulkan sebanyak-banyaknya derma. Tidak cuma saudagar dan orang kaya sahaja menyumbang harta, bahkan orang papa sekalipun. Mereka bangga dapat memberikan beras hingga telur ayam yang hendak dieraminduknya. Terkumpullah perhiasan, wang, lada, pala, cengkeh, padi, dan segala benda lainnya yang berwujud 20 kilogram emas. Kemudian semuanya disumbangkan kepada kaum selagi berada di hujung tanduk kemerdekaan. Kelak, bahkan seorang saudagar dari tanah kami menyumbang 28 kilogram emas untuk dipajang di puncak tugu nasional di depan istana Karno.

(Lampuki, 2011, p. 27)

Petikan tersebut menunjukkan bahawa masyarakat atau bangsa Acheh dahulu digambarkan 
dalam novel sebagai bangsa yang kuat dan tidak terkalahkan. Namun, hal itu berubah ketika Karno datang ke Acheh dan membujuk Teungku Daud supaya mahu bergabung dan membebaskan Jawa daripada belenggu kolonial Belanda. Pada akhirnya, dengan bangga bangsa Acheh membantu bangsa seberang laut itu. Dalam hal ini, Jawa sekaligus membentuk negara kesatuan bawah pimpinan Karno.

Dengan bergabung ke dalam negara Indonesia, maka setiap lapis masyarakat Acheh mengharapkan perlindungan hukum dari negara yang telah memproklamasikan kemerdekaan pada 17 Agustus 1945 itu. Wujud daripada perlindungan terhadap warganegara adalah hak warganegara yang sama di mata undang-undang. Namun, yang menjadi persoalan adalah hak itu sendiri dipakai pada konsepsi negara-bangsa. Pemegang kekuasaan negara itulah yang secara legal mempunyai hak menentukan siapa yang tidak punya hak dan siapa yang punya hak. Bangsa Acheh, yang diwakili Teungku Daud, dari awal menginginkan otonomi penuh dengan wujud pelaksanaan hukum Islam di masyarakat Acheh. Hal tersebut dapat dilihat dari perjanjian antara Soekarno dan Teungku Daud. Soekarno saat itu menyanggupi bahawa akan membebaskan masyarakat Acheh mengurus pemerintahannya sendiri. Akan tetapi, setelah bangsa Acheh memberikan sumbangan begitu banyak dari materil mahupun tenaga perang hingga Indonesia terbebas dari Belanda, Soekarno tidak menepati janjinya dengan menjadikan negara Indonesia sebagai negara kesatuan yang berpusat di Jawa. Padahal yang diinginkan dan dijanjikan adalah negara federal. Oleh sebab itu, dalam novel ini dilukiskan Ahmadi yang mengerti sejarah bangsanya berasa telah 'dijajah' dan 'dibohongi' oleh orang Jawa.

Sebelum bergabung dengan Republik Indonesia, sistem pemerintahan Acheh adalah sebuah kesultanan. Posisi sultan sebenarnya sebagai penyeimbang antara ulama dan Uleebalang (golongan yang pemerintah daerah). Kesultanan di Acheh runtuh dan menjadi bahagian Hindia Belanda (Nurhasim, 2008: 58). Ketika itu Belanda mengaburkan konsep tauhid dan jihad kerana dianggap menjadi dalih perlawanan Acheh terhadap Belanda. Uleebalang cenderung berpihak pada Belanda sehingga konflik dengan para ulama tidak dapat dihindarkan. Untuk itu Belanda membuat aturan pelarangan berdirinya organisasi-organisasi politik Islam. Meskipun Jepun juga melakukan taktik yang sama dengan Belanda, tetapi akhirnya ulama Acheh merespon aturan tersebut dengan membentuk PUSA (Perkumpulan Ulama Seluruh Acheh). Konflik antara kaum Uleebalang dan ulama memuncak hingga terjadi perang Cumbok yang dimenangkan pihak ulama. Lalu, pemerintahan Acheh jatuh pada pihak ulama (Nurhasim, 2008, p. 59-60). Pada ketika itu, dipilihlah Teungku Daud Beureuh sebagai ketua organisasi politik Islam PUSA tersebut. Dengan kata lain ketua sejuta ulama di Acheh itu secara de facto menjadi 'Bapak Orang-orang Acheh'. Cara berfikir ini bahkan dapat ditelusuri hukum adat Acheh dari kajian Amri Marzali (2012, p. 1820) dalam artikelnya berjudul "Kategori Adat dalam Budaya Melayu-Nusantara” yang menyatakan bahawa adat Acheh diserahkan pada kebijakan sultan yang merujuk pada hukum Islam.

Sebagai ketua ulama, Teungku Daud pada masa revolusi fisik (1945-1949) juga dikenal luas sebagai ketua militer Acheh, Indonesia. Hal ini menunjukkan bahawa norma hukum yang bekerja pada masa itu adalah hukum Agama, iaitu Islam, bukan hukum negara. Maknanya, dalam kerangka berfikir Agamben tentang status masyarakat Acheh saat perang dan terus berperang adalah sebagai zoe (hidup-alamiah), sebagaimana state of nature (keadaan alamiah) manusia seperti dalam karya Thomas Hobbes Leviathan yang disebut homo homini lupus atau manusia adalah serigala bagi sesamanya. Manusia terus berperang hingga akhirnya berkontrak sosial 
dengan membentuk negara. Dalam hal ini, upaya perjanjian yang bergabung dengan Negara Kesatuan Republik Indonesia adalah upaya mengakhiri perang dan hidup dengan damai. Dengan diplomasi ke PBB, Belanda tidak diperbolehkan menjajah negara yang telah diakui. Dengan kata lain, masyarakat Acheh dilarang untuk dijajah dan diserang oleh negara lain apabila telah diakui menjadi bahagian dari Indonesia oleh dunia antarabangsa. Pada titik ini biopolitik dari zoe ke bios bekerja dalam hukum global yang secara implisit mengharuskan seluruh tatanan masyarakat mengikuti sistem negara-bangsa yang demokratis. Sistem yuridis-politik yang bersumber daripada ilmu politik Barat.

\section{a. Krisis Kedaulatan}

Krisis kedaulatan dimaksudkan sebagai konsekuensi logis daripada paradoks kedaulatan yang memang bawaan daripada demokrasi moden. Dalam buku State of Exception (2005), Agamben berpendapat bahawa politik keamanan kontemporer adalah perpanjangan tangan dari krisis yang berada dalam negara konstitusi liberal setelah Perang Dunia pertama, ketika keadaan-pengecualian justeru 'menjadi aturan'. Hal ini dipertegas oleh Daniel Mcloughlin dalam disertasi doktoralnya (2011) yang membahas politik krisis dalam perspektif Agamben. Mcloughlin melihat keadaan pengecualian tidak sekadar beroperasi seperti kem Guantanamo, di Amerika pada tahun 2001 terjadi 9/11 sehingga kedaruratan untuk memerangi terorisme digaungkan kekuatan-pelaksanakonstitusi Amerika yang berasa kedaulatannya terancam.

Konstitusi dibentuk oleh constituting power (kekuatan-pembentuk-konstitusi) iaitu rakyat. Akan tetapi, kehendak rakyat diwakili oleh constituted power (kekuatan-pelaksana-konstitusi) yang dapat secara serampangan membuat keputusan kedaruratan. Zona tumpang tindih antara kekuatan-pembentuk-konstitusi dan kekuatan-pelaksana-konstitusi ini menghasilkan krisis. Dengan kata lain, kekuatan-pembentuk-konstitusi adalah rakyat justeru harus diatur oleh pelaksana konstitusi, iaitu penguasa. Penguasa memiliki nilai subjektif untuk melihat kondisi suatu negara. Dari situlah dalam novel ini digambarkan terjadi krisis berdasarkan penilaian penguasa. Dalam subjudul 'Jeritan yang Menyelamatkan' dijelaskan operasi militer yang pernah terjadi pada saat Orde Baru, disebut Tahun-tahun Pembantaian, seakan-akan hendak terulang kembali setelah tokoh Ahmadi digambarkan menyerang militer di jalan raya.

Mereka tidak pula menyita wang dan perhiasan sebagaimana yang pernah terjadi pada Tahun-tahun Pembantaian yang baru sahaja berlalu dan kemungkinan sedang terulang kembali sekarang ini. . . mereka datang bukan semata menjalani tugas mencari dan memburu pembangkang, tetapi mereka hadir lantaran kemarahan yang disebabkan ulah si Kumis Tebal.

(Lampuki, 2011, p. 199) 
Pada masa Orde Baru di Indonesia, wilayah Acheh ditetapkan sebagai Daerah Operasi Militer (DOM) disebabkan keinginan untuk terlepas dari negara kesatuan Indonesia. Dengan euforia kebebasan reformasi, GAM kembali membangun kekuatan dalam narasi novel ini melalui tokoh Ahmadi. Untuk itu, Ahmadi menjadi penyambung perjuangan Hasan Tiro, pendiri GAM, untuk memerdekakan Acheh dari jajahan Jawa. Meskipun orde berubah, operasi militer di Acheh tetap dilaksanakan dalam versi lunak. Dengan kata lain, krisis kedaulatan versi penguasa sedang terjadi bukan untuk mengamankan rakyat Acheh dari bahaya, melainkan militer digerakkan untuk mengamankan teritori dan hukum konstitusi NKRI di Acheh.

Sikap lunak itu memang disengaja, khusus bagi kampung yang berdekatan dengan kota, dengan tujuan agar tidak menimbulkan kerusuhan hebat yang dapat menghambat dan melumpuhkan perdagangan serta jalannya roda pemerintahan. Lain ceritanya yang terjadi di sejumlah kampung di pelosok dan bagi mereka yang tinggal berdekatan dengan gunung. Di sana penjajah bebas melakukan apa sahaja sekehendak hati. . . begitu tiba di Pasar Simpang mereka berteriak-teriak, bersorak-sorak sambil melepaskan tembakan ke udara . . . jelas sekali gelagat mereka memang hendak membantai penduduk, menganggap kampung ini sama halnya dengan kampung pelosok yang dapat mereka perlakukan sesuka hati agar penduduk kampung ini tahu diri.

(Lampuki, 2011, p. 200)

Para anggota GAM dan masyarakat awam Acheh adalah bahagian warga negara NKRI yang ikut membayar cukai ke negara. Seharusnya, diceritakan dalam novel ini, negara melindungi mereka. Selain itu, mereka adalah rakyat yang memiliki hak atas kehendak bersama yang disebut kedaulatan rakyat. Kedaulatan rakyat adalah asas daripada kekuatan-pembentuk-konstitusi, yang kemudian pelaksanaan konstitusi tersebut diserahkan ke pemerintah. Maknanya, aspirasi GAM mahupun masyarakat Acheh seharusnya didengar sebagai problem sosiologis bangsa, bukan menutup kehendak itu sekadar sebagai ancaman kedaulatan NKRI. Sudah tentu perbuatan Ahmadi yang menyerang seorang tentara dapat dijelaskan secara undang-undang sebagai penjenayah, tetapi bukan menjadikannya sebagai ancaman terhadap masyarakat kampung Lampuki yang tidak mengetahui apa-apa. Hal inilah yang memperlihatkan terjadi krisis kedaulatan dalam novel Lampuki.

\section{b. Politisasi Hidup}

Setelah biopolitik masyarakat Acheh menjadi warga negara Indonesia, hidup-politik yang didambakan penuh dengan kedamaian dan kesejahteraan — disebut polis dalam istilah Aristotelestidak serta-merta tanpa persoalan sama sekali. Setelah konstitusi dibuat muncul kekuatanpelaksana-konstitusi yang sekaligus dapat menjadi kekuasaan-berdaulat. Tidak hanya sampai pada titik menjadi warga negara (hidup-politik), melainkan juga semua orang diserap dan diikat dalam kekuasaan-berdaulat untuk bersifat produktif bagi penyelenggaraan tatanan. Maknanya, orientasi 
kekuasaan-berdaulat bukan pada teritorial semata atau status kewarganegaraan, melainkan orientasi hidup dikendalikan. Itulah yang disebut politisasi hidup, yang adalah bentuk biopolitik dalam wadah negara hukum.

Bagi Agamben, apabila hidup manusia adalah hidup yang diatribusikan dengan status politik, maka kemanusiaan kemudian selalu terwujud dalam hubungannya dengan keputusan politik pemegang otoriti kekuasaan (Sudibyo, 2019, p. 63). Maknanya, terdapat penjahitan ideologi, orientasi hidup atau interpelasi - dalam istilah Althusser-kepada kehidupan warga negara. Penyeragaman atas orientasi hidup bukan bermakna ditampilkan secara transparan, tetapi secara hegemonik. Dengan merumuskan kemanusiaan versi satu pihak adalah bukti daripada penyeragaman kehidupan atau politisasi atas hidup sedang terjadi.

Soal penyeragaman hidup dalam novel Lampuki tampak ditampilkan pada pemodenan, lebih tepatnya berada dalam lingkup lingkungan hidup masyarakat Acheh yang menjadi begitu berbeza dari sebelumnya. Arafat Nur mengisahkan ini dengan penekanan secara kronologis pada perubahan kampung Lampuki, Lamlhok dan sekitarnya. Awalnya kampung Lampuki sekadar kampung terpencil di wilayah perbukitan, dan tidak terlalu jauh dari situ terdapat kampung dengan kondisi yang sama iaitu kampung Lamlhok dan Lhoksukon. Relasi antar kampung ini berubah ketika kampung Lhoksukon banyak didirikan kilang. Hal ini dapat ditemukan dalam petikan berikut.

Tak lama beranjak setelah tahun-tahun itu, aku dan orang-orang segera terbiasa menyaksikan kenderaan-kenderaan besar dan alat-alat berat yang digerakkan mesin laksana benda sihir yang patuh mengikuti kehendak manusia. Kelak, kami sekalian tahu kalau benda-benda itu sengaja didatangkan dari Amerika melalui bandar yang dibuat khusus untuk kepentingan pengeboran dan pembangunan dua kilang gas raksasa yang kemudian diikuti dengan tiga kilang lainnya.

Kilang mula-mula didirikan di Lhoksukon, lalu di Batuphat. Kilang-kilang itulah yang menguras dan mengeruk kekayaan alam dari perut bumi tanah Pasai untuk kepentingan pemerintahan di seberang pulau sana.

(Lampuki, 2011, p. 53-54)

Dengan pendirian kilang, banyak ladang dan gunung ditebang dan tanah menjadi tandus. Lalu, masyarakat berpindah pekerjaan menjadi buruh kilang. Bentuk pemodenan ini dianggap paling sesuai dengan kondisi seluruh bangsa Indonesia, tetapi dalam novel ini tidak digambarkan demikian. Masyarakat Acheh tidak berasakan kesesuaian antara antropologi masyarakat dengan asimilasi begitu sahaja produk budaya lain. Masyarakat dikehendaki pergi ke sekolah untuk mendapatkan ijazah hanya untuk dapat bekerja sebagai buruh kilang. Semenjak saat itu sekolahsekolah umum banyak dibangun di sekitar kampung tersebut. Perhatikan petikan berikut.

Pada masa itulah Lamlhok berubah menjadi kota besar, megah, dan mahal. Pemerintahan kabupaten yang mula-mula berpusat di Lhoksukon segera dipindahkan ke tengah-tengah timbunan paya, dan tempat itu pun semakin ramai 
serta berkembang pesat dengan berbagai bangunan kedai-kedai kukuh; dari toko kain, pakaian jadi, toko emas, kelontong, kedai minuman, rumah penginapan, gedung film, tempat segala macam hiburan, sampai rumah bordil. Semuanya tersedia dan disediakan bagi mereka yang berduit banyak dan haus akan hiburan.

$$
\text { (Lampuki, 2011, p. 56) }
$$

Kondisi bios ini, yang diharapkan memunculkan perasaan aman pada setiap penduduk, justeru membuat kekuasaan-pelaksana-konstitusi berleluasa dalam mengambil kebijakan yang berdampak buruk bagi masyarakat Acheh. Pemodenan ini tidak berdampak positif bagi masyarakat Acheh sebab majoriti penduduk Acheh tidak dilibatkan dalam kebijakan, tetapi hanya menjadi kelas 'bawah' atau 'buruh' upahan sahaja. Padahal, masyarakat Acheh terlebih dahulu menempati wilayah Acheh.

Dampak daripada kebijakan yang mengeksploitasi penduduk Acheh dan sumber daya alamnya adalah sentimen ras. Hal ini juga pada orientasi kekuasaan bukan sahaja pada teritorial atau status kewarganegaraan seseorang, tetapi pada tubuh dan cara tubuh dikendalikan. Dikotomi ras antara bangsa Jawa, sebagai pendatang, dan bangsa Acheh menjadi letak perbezaan bekerja secara sentimentis. Sebagaimana Hyun (2020, p. 57-58) dalam artikelnya tentang konflik silang-budaya antara pekerja menyatakan perlunya memanfaatkan kelebihan budaya masing-masing daripada pekerja yang berbeza orientasi kebudayaan melalui sinergi budaya demi kepentingan bersama. Namun, masyarakat tanah rencong tiada pendekatan sinergi budaya sehingga lempar-melempar stigma menjadi kebiasaan kerana soal ketimpangan pembahagian pekerjaan antara kaum pendatang dan masyarakat Acheh. Hal tersebut disahkan dalam bentuk sekolah umum untuk mendapat ijazah guna memperoleh pekerjaan. Apabila tidak memiliki ijazah, maka hanya pekerjaan rendahan yang didapatkan tanpa peduli masyarakat Acheh sendiri. Perhatikan petikan berikut:

[...] tapi ayahku harus menggigit jari kerana tak punya ijazah sekolah. Orangorang pendatang dengan mudah memperoleh tempat terhormat, menduduki jabatan-jabatan penting, sedangkan penduduk pribumi sudah cukup senang bila mereka masih diterima sebagai buruh kasar.

$$
\text { (Lampuki, 2011, p. 54) }
$$

Politisasi hidup dengan paradigma kemodenan tanpa melihat keadaan masyarakat Acheh tersebut memunculkan pemberontak yang merasa dirugikan. Penindasan dengan aturan negara tersebut menjadi sah kerana dimasukkan secara lembut dalam kebijakan sekolah, kilang dan sebagainya. Hak atas menentukan hidup sendiri masyarakat dihalangi oleh lapisan-lapisan hukum yang menguntungkan satu golongan, dan merugikan golongan yang lain. Dengan begitu, munculnya pemberontakan tidak dapat dihindarkan sebagaimana tampak dalam petikan berikut:

Begitu juga pemberontak, selaku orang yang tertindas dan selalu dalam kungkungan kezaliman, pasti tidak bakal tahan menanggung sabar. Mereka pun punya hak untuk menentang dan melawan. Siapakah orang yang sanggup tahan atas penindasan? Dan, siapakah orang yang rela tanah dan agamanya dinista oleh 
sekelompok orang tidak beradab? Selemah apa pun orang yang telah jera terusmenerus ditimpa azab, pastilah akan melawan meskipun jiwanya jadi taruhan.

(Lampuki, 2011, p. 40)

Siapa yang disebut atau dilabeli dengan kata 'pemberontak' menjadi ketentuan daripada pemegang kekuasaan. Mereka disebut pemberontak kerana melawan pemerintahan yang sah di suatu negara. Tetapi di sisi yang lain, justeru yang disebut pemberontak ini adalah orang tertindas yang menuntut keadilan. Orang-orang pemberontak dipersepsikan buruk oleh negara demi melindungi kekuasaannya. Padahal di sisi pemberontak, negaralah yang melakukan kejahatan dengan menindas dan menzalimi rakyatnya. Dengan demikian, subjektivikasi (mengada) manusia ditentukan. Dengan demikian, hal yang baik dan yang buruk telah diletakkan dan diukur berdasarkan ideologi negara.

Foucault menginvestigasi 'proses subjektivikasi' dari zaman kuno sampai moden dalam kawalan kekuasaan (Agamben, 1998, p. 71). Hospital dan penjara menjadi fokus kajian Foucault. Sedangkan bagi Arendt, hukum yang dihilangkan menjadi alat untuk mengawal tubuh manusia. Bagi Agamben, justeru hukum itulah yang membuat hidup dipolitisir sedemikian rupa. Penentuan siapa yang dianggap pemberontak dan siapa yang dianggap pahlawan ditentukan oleh penguasa. Hal ini seperti yang dituliskan Hasan Tiro, pendiri GAM, dalam bukunya berjudul Demokrasi Untuk Indonesia (1999) seperti petikan berikut:

[...] Indonesia adalah suatu bangsa di mana ratap tangis satu golongan menjadi tertawaan golongan lain; di mana orang-orang yang dianggap pahlawan oleh satu golongan dianggap pengkhianat oleh golongan lain; di mana kekejaman terhadap satu golongan dipandang keadilan oleh golongan lain; di mana "solidaritas nasional" hanya ada di bibir dan di poster-poster sahaja. Nyatalah di alam kenyataan kesedaran kebangsaan Indonesia yang sesungguhnya tidak ada, dan yang disebut "nasionalisme Indonesia" itu hanya nasionalisme suatu golongan terbesar yang mempertopengkan nama "nasionalisme Indonesia" untuk membenarkan dan mengesahkan kekuasaannya. . . ....] Indonesia adalah satu negara besar yang terdiri dari keluarga bangsa-bangsa Indonesia yang masing-masing tidak dapat melupakan dirinya. Dalam keadaan yang demikian, kalau suku bangsa itu menghidupkan 'Nasionalisme'nya, maka yang lain, akan memberi reaksi yang demikian.

(Tiro, 1999: 67)

Nyatalah perbuatan Soekarno itu bukan sahaja di luar hukum, tetapi juga melanggar moral falsafah ketatanegaraan yang ber-Undang-Undang Dasar .

(Tiro, 1999: 14) 
Sebagaimana pemikiran Hasan Tiro yang menjadi dasar GAM bergerila, nasionalisme dari pemerintah pusat yang majoriti suku Jawa menimbulkan dikotominya bahawa ada masyarakat yang tidak nasionalis. Ibarat pembangkang biner, nasionalisme di Jawa dengan sendirinya menimbulkan pihak yang dirasa tidak nasionalis. Hal tersebut menimbulkan kepentingan golongan di atas golongan lain. Melalui pemodenan, dianggap suku Jawa yang memegang autoriti pemerintahan dianggap menjajah suku Acheh. Dengan pemodenan teknologi, memang pekerjaan menjadi efisien. Namun, dampaknya adalah pengurangan tenaga kerja yang hendak digantikan oleh mesin-mesin produksi. Dari sini antropologi masyarakat Acheh yang awalnya petani kemudian ditransformasikan menjadi masyarakat industri. Bukan sebagai pemegang peranan pada industrialisasi di daerah mereka, penduduk Acheh malah menjadi buruh kilang yang didirikan pemerintah pusat.

Dalam soal ini, tokoh Ahmadi dalam novel ini melarang anak-anak untuk bersekolah yang kurikulumnya dibuat negara. Sementara, di sisi yang lain Ahmadi mengunjungi tempat pengajian anak-anak yang menimba ilmu agama. Hal ini menunjukkan bahawa setelah ada indoktrinasi ke dalam penduduk, politisasi hidup juga dilakukan dengan mewajibkan bersekolah supaya mengerti hidup yang baik versi penguasa. Politisasi hidup yang lain terjadi saat anak-anak mengaji yang sebenarnya internalisasi hukum agama. Jadi, politisasi bentuk hidup telah dimulai diinternalisasi daripada masih usia dini.

Bentuk kehidupan daripada anak-anak masyarakat Acheh digambarkan dalam novel bahkan telah dibentuk; mulai dari bersekolah, dapat ijazah, bekerja untuk kilang negara, menikah, lalu mati, dan sekaligus ditambah versi agama iaitu masuk syurga. Dalam buku Means Without End, Agamben (1996, p. 3-4) mendefinisikan hidup sebagai 'that can never be separated from its form' Yang dimaksud dengan form-of-life hanya dapat difahami dalam relasinya dengan hidup yang dibentuk dalam tradisi yuridis-politis Barat. Tradisi yuridis tersebut tampak daripada kebijakan yang berdampak di sekitar masyarakat Acheh, iaitu dibangunnya kilang, lalu kewajiban sekolah formal untuk dapat ijazah demi menjadi buruh di kilang. Terus seperti itu bagaikan lingkaran hidup yang telah dikonstruksi penguasa. Sementara forms of life berarti variasi hidup yang tidak dibentuk oleh aparatus kekuasaan yang bekerja mengawal kehidupan.

Bahkan tentang rights of death (hak atas kematian) seperti hukuman mati dinyatakan oleh penguasa walaupun secara implisit, seperti tampak dari subjudul 'Si Pedagang Ganja'. Tokoh Karim adalah pedagang ganja yang juga kaki tangan Ahmadi. Ganja-ganja ditanam dan diperdagangkan untuk membeli senjata. Di sini senjata sebagai alat perang dan membunuh didapatkan daripada jeneral-jeneral militer di Jakarta. Jadi, senjata justeru dipasok daripada musuh sendiri. Politisasi tubuh telah terjadi dalam biopolitik Indonesia. Hujung dari politisasi tubuh tersebut adalah rights of death (hak atas kematian) warganegara melalui perang yang dibuat langgeng tidak berkesudahan.

Sedikit banyaknya perkara ganja punya kaitan dengan senjata, Karim menjelaskan. Gerilawan memiliki banyak senjata. . . sebahagian senjata merupakan hasil rampasan dari tentera dan polis ...

Bukan lagi rahsia, para mafia Jakarta, yang juga berasal dari kalangan tentera pemerintah, para jenderal putus asa dan tidak punya jabatan apa-apa selian mereka hanya memelihara kedunguan, secara diam-diam melelong senjata sejenis M-16 dan pistol FN hasil buatan Pindad, kilang senjata negara, kepada

e ISSN 2735 - 1904

https://doi.org/10.22452/JOMAS.vol32no1.10 
para pemberontak. Senjata-senjata itu tidak laku dijual ke negeri lain kerana mutunya amat jelek dan pembangkang kurang peduli akan ukuran kadarnya yang sangat buruk dan laju pelurunya kerap melenceng.

(Lampuki, 2011, p. 170-171)

Hal ini menunjukkan bahawa justeru peperangan antara pemberontak dan militer itu keduaduanya disokong oleh pemerintah. Demi perniagaan dan demi wang, mafia menjual sahaja senjatasenjata yang tidak layak digunakan itu kepada para pemberontak. Dari satu sisi, pemberontak juga senang mereka memiliki senjata untuk melawan, kalaupun mati mereka mati syahid. Di sisi yang lain, pemerintah mempolitikkan tubuh-tubuh pemberontak dan militer untuk diadu satu sama lain, sebagaimana petikan novel berikut.

Namun, ada pula yang mengatakan bahawa penjualan senjata itu memang sengaja dilakukan segelintir pentolan junto militer untuk memelihara kericuhan dan pertikaian di Acheh agar tetap abadi, agar tentera punya kerjaan dan para jenderal punya alasan mengajukan projek kepada rejim pemerintah sehingga mereka dapat menguras wang negara dalam jumlah sangat besar.

(Lampuki, 2011, p. 173)

Petikan tersebut menunjukkan bahawa sentimen antipusat yang memunculkan GAM justeru dimanfaatkan sebagai lahan perniagaan penguasa. Dikotomi hitam putih antara pemberontak dan militer dengan sendirinya menyatu dalam hidup masyarakat Acheh. Jalur politisasi hidup berkembang dari anak ideologis Hasan Tiro, seorang proklamator GAM (Gerakan Acheh Merdeka). Hal ini ditunjukkan dengan penggambaran tokoh Hasan Tiro yang mengetahui sejarah bangsa Acheh sehingga mengambil keputusan memberontak pusat. Ahmadi digambarkan dengan cara yang sama saat di awal-awal cerita dalam novel, seperti petikan berikut.

Aku tidak tahu dari mana Ahmadi menemukan asal-usul indatu dan bentuk kesultanannya. Tambah berapi-api pula dia memaparkan gagasan tegaknya sebuah negeri sebagaimana yang digambarkannya dalam khotbah kerajaan silamnya yang semuanya sudah runtuh dan tidak meninggalkan bekas.

(Lampuki, 2011, p. 34-35)

Cara Ahmadi menghuraikan sejarah itu amat bersahaja, disertai pula gerakan tangannya yang melingkar-lingkar dan berkali-kali hampir mengenai mukaku. Lagaknya seolah-olah dia ahli sejarah dunia yang paling pandai dan telah dapat banyak lencana penghargaan. Barangkali, ini adalah kesempatan pertama dia berbicara di hadapan khalayak ramai sungguhpun mereka hanyalah kawanan anak-anak bengal, 
dan jumlah mereka cuma dua kelas.

(Lampuki, 2011, p. 35)

Petikan tersebut menunjukkan bahawa Ahmadi menjadi anak ideologis Hasan Tiro yang pengetahuan sejarah bangsa Acheh begitu luas. Pada akhirnya, Ahmadi menyebarluaskan pengetahuan tersebut seperti disampaikannya kepada murid-murid Teungku Muhammad. Di titik inilah masa kanak-kanak masyarakat Acheh dengan sendiri diberlakukan politisasi hidup, pada segi ekonomi mahupun pada segi ideologis.

\section{c. Homo Sacer}

Bagi Agamben (1998: 9), seluruh warga negara dalam negara demokrasi kontemporer adalah homo sacer, iaitu manusia yang sama sekali tidak mempunyai perisai undang-undang. Untuk memperlihatkan fakta tersebut secara eksplisit, homo sacer dapat dikaji daripada state of exception negara terhadap warga negara tertentu, dalam hal ini masyarakat Lampuki. Agamben menyatakan bahawa hubungan azali antara negara dan warganya adalah penelantaran. Hal inilah yang terjadi pada masyarakat Lampuki yang semena-mena diseksa dan dibunuh tanpa proses pengadilan sama sekali. Dalam subbab 'Perihal Terbunuhnya Dua Penduduk Lampuki' di novel Lampuki diterangkan kemalangan masyarakat Lampuki melalui suara Teungku si guru mengaji. Perhatikan petikan berikut.

Kemalangan demi kemalangan terus berlanjut, menimpa orang-orang kampung yang kadang membuatku gundah, sedih, dan bingung sendiri. Aku yakin, mereka yang kebanyakan mati terbunuh tiada punya sangkut paut dengan kelompok pergerakan kerana mereka yang membangkang sudah nyata bagi kami.

(Lampuki, 2011, p. 278)

Padahal penduduk Lampuki juga merupakan warga negara yang wajib dilindungi. Pada bab 'The Decline of the Nation-State and the End of the Rights of Man' di buku Imperialism, Hannah Arendt secara paradoksal mempersoalkan kaitan erat antara konsep Hak Asasi Manusia (the rights of man) dan negara bangsa (Sudibyo, 2019, p. 154). Dari sini hak asasi menjadi bermakna dan dianggap ada untuk seluruh warganegara, baik GAM mahupun masyarakat awam, apabila dalam terjemahan negara. Jadi, fakta penelantaran terhadap GAM dan masyarakat awam bermula sejak penyatuan hak asasi dalam negara bangsa. Akhirnya kekerasan terhadap GAM dan masyarakat awam Acheh diperbolehkan demi keamanan nasional semata.

Dalam segi ekonomi, warganegara diinklusikan oleh negara kerana masih membayar cukai. Warganegara yang baik adalah warga yang membayar cukai. Untuk itu, inheren di dalamnya perlindungan terhadap pembayar cukai, yang disebut warganegara. Namun, pengecualian dan penelantaran negara juga dialami pembayar cukai. Dengan demikian, keperluan negara pada warga Acheh kerana masih dapat dieksploitasi sumber dayanya. 
Di samping itu, dalam novel ada tokoh yang berprofesion sebagai pemungut cukai daripada kalangan GAM, iaitu Halimah, isteri Ahmadi pada bahagian lapan novel ini dengan subjudul 'Perempuan Pengutip Pajak dan Jibral si Rupawan'. Berbeza dari negara yang mewajibkan cukai dengan tanpa bertemu secara langsung sehingga dimensi emosi dari pertemuan itu terkikis. Artinya, tiada perlakukan khusus kepada mereka yang sengsara dan melarat sekalipun, yang dipentingkan negara adalah membayar cukai sesuai beban. Halimah tidak demikian, dia membezakan petani dan masyarakat miskin seikhlasnya bahkan boleh tidak membayar cukai.

Pengusaha, saudagar, tuan tanah, dan pejabat-pejabat kaya sahajalah yang paling besar pungutannya. Sedangkan mereka yang melarat, sebagaimana jamaknya petani Lampuki, semua terbebas dari kewajiban itu. Terkecuali, jika ada satu dua orang yang dengan sukarela memberikan, tangan Halimah tiada pernah menolak.

(Lampuki, 2011, p. 136)

Daripada petikan tersebut, penduduk Acheh dalam novel ini digambarkan harus membayar cukai kepada pihak GAM demi perjuangan kemerdekaan Acheh untuk melawan pemerintah pusat. Pada saat yang sama, penduduk juga harus membayar cukai kepada negara demi mendapat perlindungan, khususnya daripada pemberontak. Padahal sumber konflik adalah ketegangan antara GAM dan pemerintah. Masyarakat awam tidak berpartisipasi sepenuhnya di dalamnya tetapi diinklusi (dilibatkan) dan pada masa yang sama dieksklusi (dibuang), iaitu dilibatkan sebagai sumber logistik pada masa yang sama dibuang kerana konflik. Dengan kata lain, terdapat eksploitasi terus-menerus terhadap masyarakat awam Acheh.

\section{Kesimpulan}

Bergabungnya masyarakat Acheh ke negara Indonesia memunculkan masalah biopolitik iaitu transformasi zoe ke bios meninggalkan ruang yang tidak dihitung oleh pemikiran filsafat barat selama ini. Ruang antara itu adalah bare life (hidup telanjang). Hidup masyarakat berada dalam ambang inklusi dan eksklusi yang menimbulkan politisasi hidup. Orientasi hidup diarahkan dan pada masa yang sama dieksploitasi terus-menerus. Hal ini ditambah dengan faktor sejarah pengkhianatan Karno yang dirasakan masyarakat. Untuk itu, krisis kedaulatan dalam novel mendapatkan momentumnya.

Krisis kedaualatan tersebut dirasmikan oleh negara dengan deklarasi darurat militer, yang dalam pemikiran Agamben disebut State of exception. Pada akhirnya state of exception melahirkan figur homo sacer yang adalah masyarakat awam. Di titik ini, novel Lampuki tidak sekadar menampilkan sejarah permasalahan biopolitik di Acheh, melainkan juga menampilkan eksploitasi hidup lebih jauh daripada biopolitik dan krisis kedaulatan tersebut. 


\section{Rujukan}

Agamben, Giorgio. (1998). Homo sacer: Sovereign power and bare life. California: Stanford University Press. . (2005). The state of exception. Illinois: The University of Chicago Press.

Amnesty International. (1993). “Indonesia shock theraphy (Restoring order in Acheh 1989-1993)". Retrieved from https:/www.amnesty.org/en/documents/ASA21/007/1993en/. . (2004). "Indonesia: Operasi-operasi militerbaru, pola lama pelanggaran HAM di Acheh (NAD)". Retrieved from https:/www.amnesty.org/ download/Documents/96000/asa210332004in.pdf .

Muhammad Alfian. (2019). "Novel Maryam sebagai kritik terhadap politik kedaulatan dan politik kewargaan di Indonesia". Tesis. Fakultas Ilmu Budaya. Yogyakarta. Tidak diterbitkan.

Armet, Iswadi Bahardur, Yulia Sri Hartati. (2019). "Multikonflik dalam novel Lampuki karya Arafat Nur”. Magistra Andalusi: Jurnal Ilmu Sastera, Vol. 1, No. 1. https:// doi.org/10.25077/majis.1.1.2.2019.

Azhari Ayub. (2004). Perempuan Pala. Yogyakarta, Indonesia: AKY Press.

Fauzi Hassan, Tengku Intan Marlina Mohd Ali, Madiawati Mamat@Mustaffa. (2019). Subjektiviti dalam novel-novel terpilih Faisal Tehrani. Jurnal Pengajian Melayu/ Journal of Malay Studies (JOMAS), 30(1), 28-52. Retrieved from https://ejournal. um.edu.my/index.php/JPM/article/view/21222.

Kim, K. (2014). Konflik silang-budaya antara pekerja Melayu dan pekerja Korea dari segi pengelakan ketidakpastian dan orientasi masa. Jurnal Pengajian Melayu/Journal Of Malay Studies (JOMAS), 25(1), 45-61. Retrieved from https:/ejournal.um.edu.my/index. $\mathrm{php} / \mathrm{JPM} /$ article/view/9757.

Laporan Khusus Tempo. (2003). "Beureueh, pemberontakan dengan sebab klasik”.

Edisi 17 Agustus 2003. Retrieved from https://majalah.tempo.co/read/laporan-khusus/89642/ beureueh-pemberontakan-dengan-sebab-klasik.

Amri Marzali. (2020). Kategori adat dalam budaya Melayu nusantara. Jurnal Pengajian Melayu/ Journal Of Malay Studies (JOMAS), 23(1), 1-25. Retrieved from https://ejournal.um.edu. my/index.php/JPM/article/view/25676.

Arafat Nur. (2011). Lampuki. Jakarta, Indonesia: Serambi.

Moch Nurhasim. (2008). Konflik dan integrasi politik gerakan Acheh merdeka: Kajian Tentang Konsensus Normatif antara RI-GAM dalam Perundingan Helsinki. Yogyakarta, Indonesia: Pustaka Pelajar.

Eko Cahyo Prawoto. (2016). "Totalitarianisme dalam novel Lampuki karya Arafat Nur”. Buana Sastera, Vol. 3, No. 1, 91-103. 
Helvy Tiana Rossa. (1999). Jaring-jaring merah. Jakarta, Indonesia: Majalah Horizon.

Agus Sudibyo. (2019). Demokrasi dan kedaruratan: Memahami filsafat politik Giorgio Agamben. Serpong: Marjin Kiri.

Tempo Edisi Wawancara. (2007). "Hina Jilani: Pelanggaran ham terbanyak di Acheh dan Papua". Edisi 18 Juni 2007. Retrieved from https://majalah.tempo.co/read/ wawancara/124261/hina-jilani-pelanggaran-ham-terbanyak-di-Acheh-dan-papua.

Hasan Tiro. (1999). Demokrasi untuk Indonesia. Banda Acheh, Indonesia: Bandar Publishing. 